NAGY PÁL ${ }^{*}$

\title{
„Ó, kérem, én magamnak játszom.”
}

Kutatási témám negyedszázada a Kárpát-medence cigány népességének története. Pontosabban, a történeti Magyarország területén keletkezett forrásokban cigányoknak nevezett emberek története. Ez nem külön történelem, hanem Magyarország történetének része, és elválaszthatatlan annak eseményeitől, gazdasági és társadalmi változásaitól. Arról fogok beszélni, hogy ennek a témának a kutatása miért és hogyan jelent ambivalens helyzeteket, hol húzódik a határ, ameddig ez a téma otthonosságot jelent számomra, és e határon túl miért változik otthontalansággá.

1991-ben került a kezembe levéltárosként cigányokról szóló történeti forrás. Érdeklődésemet az iratok keltették fel, nem jelenbeli társadalmi problémák vagy politikai, ideológiai megfontolások. A cigányokról való beszéd anomáliái már ekkortájt jelentkeztek, de még nem érintettek meg közvetlenül. Az első, a meglepődésnél erösebb hatás akkor ért, amikor 1998-ban a könyvem megjelenése után a hazai cigánykutatók idősebb generációjához tartozó egyik szociológus azon sjnálkozott, milyen kár, hogy ezt a könyvet nem cigány írta.

A következő másfél évtizedben kerestem azokat a kutatási irányokat, amelyek iránt érdeklődés mutatkozhat, de nem adtam fel a forráskritikai megközelítést, és kutatásaimat a múltbéli realitások megismerésére irányuló munka belső logikája szerint igyekeztem felépíteni, nem pedig jelenbeli kívánalmakhoz igazodva. Tanulmányok írásával párhuzamosan forráskiadással próbáltam megteremteni azt a bázist, ami lehetővé teszi egyáltalán az értelmezhető beszédet. Rövid idő alatt be kellett látnom, hogy amibe belekeveredtem, nem a tudományos megismerésröl, hanem a diskurzus irányításáért folyó harcról szól. Történeti vonatkozásban arról, hogy kinek legyen joga és támogatottsága a cigányok múltjáról beszélni és azt kitalálni.

Keserü tapasztalat volt, hogy az akadémikus történészekben nincs érdeklődés a cigányok iránt. A romológia szakon, ahol mintegy tíz évig tanítottam, úgy néztek a történelemre, mint szükséges rosszra. A társadalomkutatók egy része számára az értelmiségi attitüd és a romákkal szembeni szolidaritás reprezentálása fontosabb volt, mint a múlt megismerése. Történelemről csak az elnyomás és a jelenben érvényes társadalmi aktivizmus kontextusában, a jelenben érvényes fogalmi keretekben lehetett velük beszélni.

\footnotetext{
* A szerző történész, a Társadalomtudományi Kutatóközpont Kisebbségkutató Intézet munkatársa. E-mail: Nagy.Pal@tk.hu
} 
Bármit csináltam ezekben az években, mindig azt kaptam, fantasztikus, nagyon érdekes, de minek ez, egyébként is hadd legyen már úgy ahogy szeretnénk. Időnként egyik sértés ért a másik után. Minden kutatási problémánál nagyobb kihívást jelentett megérteni ezek okát. Amikor cigányperek korabeli dokumentumait adtam ki, megkaptam, hogy kriminalizálom a cigányokat. A Kemény-féle munkacsoport egyik tagjával a forrásokról beszélgettem, és ő kijelentette: azért nem használ forráskiadványokat, mert a levéltárosok kényük-kedvük szerint változtatják meg a szövegeket. Ez volt a legnagyobb sértés, amit valaha kaptam. Az egyetemi munkámban folyton abszurd elvárásokat állítottak elém, a dékán például azt akarta, szervezzek főzőversenyt cigányasszonyoknak, amire nem voltam hajlandó.

A roma aktivizmussal való találkozást sem lehetett elkerülni. Ebből az irányból képtelenségek érkeztek felém. Az például, hogy egy középkori oklevéltani kérdésbe miért kell belekeverni a roma narratívát és miért támadnak olyan személyek, akiknek ez nem szakterülete, vagy életükben nem láttak még levéltári iratot, túlment számomra a racionális megmagyarázhatóság határán. Ez ellen nem igazán tudtam védekezni, többek között azért sem, mert egy-két mozgalmár attitüdű kutató is hasonlóan gondolkodik, mások pedig passzívan eltürik, még ha ízléstelennek tartják is. Ugyanakkor szembesültem azzal is, a romák egy része pozitívan fogadta a munkámat, de más romák előtt ezt nem merte vállalni.

A 2010-es évekre részben a kényszerü, részben az önként vállalt kívülállás helyzetébe kerültem, úgy voltam benne a cigánykutatásban, hogy nem voltam benne. Éveken át nem tudtam éjszakánként aludni, és folyton az kavargott a fejemben, hogy tủzbe dobálom a munkáimat, és végleg kiszállok ebből az áldatlanságból. Jungi értelemben magányos lettem, minél többet tudtam a témámról, annál inkább csak magammal beszélhettem meg. Többnyire az elemi tények kérdésében sem lehetett előbbre jutni, az ismerethiányt kompenzálni, a mítoszgyártást ellensúlyozni. Ugyanakkor meg voltam győződve arról, hogy történetkutatóként el kell kerülnöm a morális és érzelmi elfogódottságokat, amiket számon kérnek rajtam, hiszen moralizálásból és érzelmi elvakultságból nem történelem lesz, hanem hamis múlttudat. A kívülről való rátekintést azonban a legtöbben a szolidaritás hiányának, vagy éppenséggel cigányellenességnek értelmezték, mások pedig éppen a cigányellenességükhöz igazítva torzították el. A cigányokról való beszéd visszavonhatatlanul instrumentalizálódott, amit tetézett a tudományos életben itt-ott gyökeret vert gettószemlélet is (azaz a romákra vonatkozó tudományos vizsgálódás önálló területként való definiálása).

2014-ben új irányt vett az életem. Néhány hónapig erdélyi levéltárakban kutattam. Sepsiszentgyörgyön az első napon nyitáskor álltam neki az iratoknak, és a délutáni záráskor vettem észre, hogy egész nap nem álltam fel. Elementáris erővel dolgozott bennem a kíváncsiság és az ösztönző várakozás, hogy olyasmit találok, ami különlegesen fontos. Így is történt. Megtaláltam az erdélyi cigányok 1781-es 
összeírását, amiből 12 ezer cigány család adatait tártam fel. Nem volt kétség, szeretem ezt csinálni, élvezem az iratok feltárását, az adatok összegyüjtését, ebben otthon vagyok. Nem sokkal ezután Budapesten találkoztam az akkoriban hazatelepült Szelényi Ivánnal és Ladányi Jánossal. Az ő érdeklődésük és bíztatásuk végleg megerősítette bennem, hogy nem vagyok hajlandó munkámat annyiba hagyni, nem adom fel a kutatói attitüdömet, nem hagyom lerombolni a szakmai identitásomat, a sajátszerűségemet. Elkerülök minden vitát és szituációt, ahol nem lehetséges a szakmai érvelés.

Pontius Pilatus azt mondja a Ben Hur címü filmben: okos ember tudja, milyen világban él. Számomra ennek értelme, hogy meg kell találni a kényszerü alkalmazkodás határát, ám azon túl saját magam mércéje érvényes. Néhány napja egy cikket olvastam Domján Editről. Az egyik előadás után arról kérdezték, látta-e, kik voltak a közönség soraiban? Válasza: „Ó, kérem, én magamnak játszom”. 